\title{
INHERITANCE LEGAL SYSTEM IN INDONESIA: A LEGAL JUSTICE FOR PEOPLE
}

\author{
Yeni Salma Barlinti ${ }^{1}$
}

\begin{abstract}
As one of Asian countries, Indonesia has varied of cultures and religions. This variety affects positive laws in Indonesia, one of them is inheritance law. Indonesia has three inheritance legal systems, that is, adat inheritance law, Islamic inheritance law, and western inheritance law. Adat inheritance law is a norm of local adat community about inheritance. Islamic inheritance law is a norm of inheritance based on al Qur'an (Islamic holy book) and hadis (words, acts, and silence of Prophet Muhammad PBUH). In Indonesia, there are three schools of Islamic inheritance law, that is, Syafi'i's (patrilineal) system of inheritance law (Imam Syafi'i is the most influenced school for Indonesian people), Hazairin's (bilateral) system of inheritance law (Hazairin was Profesor at University of Indonesia had different view from Imam Syafi'i), and Compilation of Islamic Law system of inheritance law (Compilation of Islamic Law is Islamic law written by Indonesian ulama and Islamic experts). The last, western inheritance law is a norm of heritage based on Burgerlijk Wetboek as legal product of Dutch government when occupied Indonesia. All three inheritance legal systems are available for Indonesian people. We are able to know the availability of these systems is from legal cases in the courts, civil court and religious court. On the paper will be explained comparison of three systems of inheritance law, legal subject using the system (personality principle), and implementation of the system in the courts.
\end{abstract}

Keywords: inheritance law, adat, Islam, civil code

\section{Introduction}

Indonesian legal system consists of three legal systems, namely, adat(customary) legal system, Islamic legal system, and western legal system. System of adat law is a legal device based on norms of local adat community. As the oldest legal system, adat law which exist in society is unwritten. System of Islamic law is a legal device based on primary Islamic sources, al Qur'an and the hadith. Indonesia has a lot of legislations that absorb Islamic law, ${ }^{2}$

\footnotetext{
${ }^{1}$ Lecturer of Islamic Law, Faculty of Law, University of Indonesia. Obtained Bachelor of Law (S.H.) from University of Indonesia (1998), Master of Law (M.H.) from University of Indonesia (2001), and a Doctor of Philosophy (Dr) from University of Indonesia (2010)).

${ }^{2}$ Legislations which absorb Islamic law are Law of Marriage (Law No. 1 Year 1974), Law of Religious Judicature (Law No. 7 Year 1989, Law No. 3 Year 2006, and Law No. 50 Year 2009), Law of Islamic
} 
applicable to muslims and for those (non-muslims) who subject to Islamic law. ${ }^{3}$ On system of western law, term of western law is used to law produced by the Dutch East India Government during its colonialization. The system of western law is a legal device based on the dutch legislation which still exist presently.

One of Indonesian legal systems is concerning inheritance law. As a legal fact, someone's death will cause legal effects to property and family left behind. The three legal systems have different rules of inheritance one to another.

\section{Systems of Inheritance Law In Indonesia}

Principally, the law of inheritance related tosociety.Hazairin stated that

"Hukum menentukan bentuk masyarakat. Masyarakat yang belum dikenal dapat dicoba mengenalnya pada pokok-pokoknya dengan mempelajari hukum yang berlaku dalam masyarakat itu : hukum mencerminkan masyarakat. Dari seluruh hukum maka hukum perkawinan dan kewarisanlah yang menentukan dan mencerminkan sistim kekeluargaan yang berlaku dalam masyarakat itu. Bentuk kekeluargaan berpokok pangkal kepada sistim (garis) keturunan".4

Translation:

Law establishestypes of society. Type of society is able to be known by learning applied-law in the society: law reflects society. Of all the law, law of marriage and inheritance define and reflectsystem of family in society. Type of family is based on descendants system.

Inheritance legal systems in Indonesia, particularly the system of adat inheritance law and the system of Islamic inheritance law, influenced by the understanding of society typeof indigenous for the system of adat inheritance law and the understanding of society type formed by al Qur'an and the hadith for the system of Islamic inheritance law.In addition to adat and Islamic inheritance law, there is system of western inheritance law based on the Civil Code or Burgerlijk Wetboekor Kitab Undang-Undang Hukum Perdata. These three systems of inheritance law are prevailing for Indonesian people but different significantly one to others.

\section{A. Inheritance Law of Adat}

Adat law has been applicable for adat local community or indigenous prior to entering of Islam and Dutch colonialization in Indonesia.Inheritance law also provided in adat law. It is hard to uniform adat inheritance law for all indigenous because familial system influenced by variety of descendents lines, namely patrilineal, matrilineal, and bilateral or parental.Patrilineal is descendent system based on father (male) descendent line. Male is superior of female.Examples of patrilineal society are indigenous ofGayo, Alas, Batak, Nias, Lampung, Buru, Seram, Nusa Tenggara, and Papua. Matrilieal is descen-

Banking (Law No. 21 Year 2008), Law of Waqf (Law No. 41 Year 2004), Law of Management of Zakah (Law No. 23 Year 2011).

${ }^{3}$ Subjection of non-muslim to Islamic law is related to Islamic economic activities.

${ }^{4}$ Hazairin,(1982). Hukum Kewarisan Bilateral Menurut Qur'an dan Hadith, Jakarta: Tintamas Indonesia, p.11. 
dent system based on mother (female) descendent line. Female is superior of male. Examples of matrilineal society are indigenous of Minangkabau and Enggano. Bilateral or parental is descendent system based on father and mother descendent lines.Examples of bilateral are indigenous of Aceh, Sumatera Timur (East Sumatera), Riau, Jawa, Kalimantan, and Sulawesi.Among descendent systems are able to mix or alternate one and another, patrilineal and matrilineal, called alternating patrilineal system.Form of descendent systems of patrilineal, matrilineal, and bilateral or parental do not form similar system of adat inheritance law in one descendent system. ${ }^{5}$

In adat inheritance law, there are three inheritance systems, namely individual, collective, and mayorat. ${ }^{6}$

1. System of individual inheritance is distribution of legacy based on individual or personal heir to be possessed individually. Each heir is free to use or transfer the obtained property to other parties. The system can be found in bilateral or parental society, such as mencar and mentas in Jawa, and patrilineal society, such as manjae in Batak or peminggir in Lampung. In matrilineal society, like indigenous of Minangkabau, there is a change of inheritance system into individual inheritance system. This is due to the heirs no longer bound to one familial house (rumah gadang) or parental home and having works in wide area. Therefore, they no longer desire to possess the property together.

2. System of collective inheritance is distribution of legacy by transferring undivided legacy to the heirs.Each heir has rights to manage, to use, or to received result of collective legacy.In indigenous of Minangkabau as matrilineal society of West Sumatera,mamak kepala warisleads the management of tanah pusakojointly conducted by the heirs who merely to use or ganggam bauntuik. In indigenous of Ambon or Maluku, tanah datiis used by the heirs in controlling of kepala dati. In indigenous of Minahasa in North Sulawesi as patrilineal system, they havekalakeran, namely familial land that should not be divided and distributed to the heirs but should be used by the heirs undercontrol and manage by tua untaranak, haka umbana, orpaki itenan tanah-tanah. Other patrilineal society, such as indegenous of Lampung in South Sumatera, they have tanah menyanak ortanah repongthat should not be distributed to the heirs but jointly managed. System of collective inheritance changes to system of individual inheritance since usage of legacy is individual and role of leader of society in legacy management is weak.

3. System of mayorat inheritance is transferring of rights to occupy undivided legacyto the eldest child considered successor of responsibility of family after his or her parents died.The eldest child manage legacy to earn living and takecare of his or her immature siblings until they are matured and independent. There are two kinds of systems of mayorat inheritance, male mayorat and female mayorat. Mayorat of male is transferring of legacy management to the eldest son. It is happpened in indigenous of Lampung

\footnotetext{
${ }^{5}$ Indigenous of Batak and Lampung have system of patrilineal descendent, but different system of inheritance law.Inheritance system of indigenous Batak is individual. Inheritance system of indigenous Lampung is mayorat. Hilman Hadikusuma,(1993). Hukum WarisAdat,Bandung: Citra Aditya Bakti, p.24.

${ }^{6}$ Ibid., 24-30. Hazairin, Hukum Kewarisan menurut Al Qur'an dan Hadith, (Jakarta: Tintamas Indonesia, 1982), 15. Abdulkadir Muhammad, (2010). Hukum Perdata Indonesia, Bandung: Citra Aditya Bakti, p.198-199.
} 
with beradat pepadun. That isanak punyimbangor the eldest son of the first wife leads, manages, and dominates undivided legacy. Mayorat of female is transferring of legacy management to the eldest daughter. This mayorat is applied in indigenous of Semendo in South Sumatera, tunggu tubangorthe eldest daughter manages and dominates legacy. System of collective and mayorat inheritance influences harta pusaka, such as house of family, lands of family, tools of ceremonial tradition, magical goods, etc.However, both system has been changed, common property of parents becomes dispute among the heirs often. Thus, it is needed to distribute the property to the heirs.

In carrying out the adat inheritance, inheritance is processed before and after the deceased died. Before the deceased dies, he or she can process inheritance through forwarding or transferring, redirecting, and will to others. After the deceased dies, inheritance can be done byoccupying and distribution of property, as well as distribution of propertybased on Islamic inheritance law.

Inheritance of forwarding or tranferring process that occurs before the deceased dies is by altering position or adat position, rights and obligations of property to heirs. ${ }^{7}$ The heirs who receive the forwarding or transferring is the eldest son in patrilineal society, the eldest daughter in matrilienal society, and the eldest son or daughter in bilateral society. ${ }^{8}$ Thus, title of the deceased property is transferred to the heirs when he or she is alive. The forwarding or tranferring usually is given to adopted child, because he or she will not accept share, based on islamic law.

Inheritance of redirecting process is by appointing particular heirs to have particular property. ${ }^{9}$ During the deceased is alive, the heirs is only able to have rights of use and rights of enjoy, but alive-the deceased has rights of controlling the property.Rights of controlling and rights of ownership are for the heirs if the deceased dies. Forwarding or transferring and redirecting is done by the deceased before the heirs, family members, and neighbors, exclude tua-tua adat. ${ }^{10}$

Wills made by the deceased when he or she is alive, feels there is no hope to stay or return home. ${ }^{11}$ If the deceased is getting better or returning home, he or she has rights to change or revoke his or her wills. The deceased must say clearly and witnessed by the heirs, family members, neighbors, and tua-tua desa. ${ }^{12}$ In islamic law, the wills is limited a third of all assets. This provision affects the implementation of wills in society. ${ }^{13}$

Process of inheritance after the deceased died, firstly, is occupying the property. Occupying of property will be occured if the property should not be divided since belongs together for all of the heirs interest or since one of parents is survived, limited property, particular type of property, immature heirs,

\footnotetext{
${ }^{7}$ Hadikusuma, ibid., 95.

${ }^{8}$ Ibid., 95.

${ }^{9}$ Ibid., 97.

${ }^{10}$ Ibid., 98-99.

11 Ibid., 99.

${ }^{12}$ Ibid.

13 Ibid.
} 
no substitute heirs, absence of some heirs, no entitled heirs, or unknown or uncleared debt of the deceased. ${ }^{14}$

Secondly, distribution of legacy conducted when the deceased died. Adat inheritance law does not determine shares of the heirs.Principle of equality of rights or principle of proporsionality is embodied in adat inheritance law. Nonetheless, this principle does not apply a ratio of $1: 1$ to distribute legacy among the heirs.Distribution of legacy often conducted based on type of property, not equation of asset value.Example, share of son is garden and share of daughter is house.In addition, distribution of property based on islamic inheritance law influence distribution of property on adat inheritance law.In indigenous of Jawa, segendong sepikulis distribution of legacy for man is equal to two women, same as islamic inheritance law stated on surah An Nisa verse 11.

Thirdly, distribution of legacyaccording to Islamic law.Most of Indonesian people are muslim, included indigenous. Therefore, islamic inheritance law often carried out by indigenous muslim.

\section{B. Inheritance Law of Islam}

Islamic inheritance law is a norm of inheritance based on al Qur'an and the hadith. In Indonesia, there are three schools of Islamic inheritance law, that is, Syafi'i's (patrilineal) system of inheritance law (Imam Syafi'i is the most influenced school for Indonesian people), Hazairin's (bilateral) system of inheritance law (Hazairin was Profesor at University of Indonesia had different view from Imam Syafi'i), and Compilation of Islamic Law system of inheritance law (Compilation of Islamic Law is Islamic law written by Indonesian ulama and Islamic experts).

In al Qur'an, surah An Nisa verses 11, 12, and 176, it is stated clearly share of each heirs. The heirs are son, daughter, father, mother, husband, wife, brother and sister of the deceased.

Translation of surah An Nisa verse 11:

God (thus) directs you as regards your children's (inheritance): to the male, a portion equal to that of two females; if only daughters, two or more, their share is two-thirds of the inheritance; if only one, her share is a half. For parents, a sixth share of the inheritance to each, if the deceased left children; if no children, and the parents are the (only) heirs, the mother has a third; if the deceased left brothers (or sisters) the mother has a sixth. (The distribution in all cases('s) after the payment of legacies and debts. Ye know not whether your parents or your children are nearest to you in benefit. These are settled portions ordained by God; and God is All-knowing, All-wise. ${ }^{15}$

Translation of surah An Nisa verse 12:

In what your wives leave, your share is a half, if they leave no child; but if they leave a child, ye get a fourth; after payment of legacies and debts. In what ye leave, their share is a fourth, if ye leave no child; but if ye leave a child, they get an eighth; after payment of legacies and debts. If the man or woman

${ }^{14}$ Ibid., 100 and 44.

15 'Abdullah Yusuf 'Ali,(1994). The Holy Qur'an: Text and Translation, Kuala Lumpur: Islamic Book Trust, p. 70. 
whose inheritance is in question, has left neither ascendants nor descendants, but has left a brother or a sister, each one of the two gets a sixth; but if more than two, they share in a third; after payment of legacies and debts; so that no loss is caused (to any one). Thus is it ordained by God; and God is All-knowing, Most Forbearing. ${ }^{16}$

Translation of surah An Nisa verse 176:

They ask thee for a legal decision. Say: God directs (thus) about those who leave no descendants or ascendants as heirs. If it is a man that dies, leaving a sister but no child, she shall have half the inheritance: If (such a deceased was) a woman, who left no child, her brother takes her inheritance: If there are two sisters, they shall have two-thirds of the inheritance (between them): if there are brothers and sisters, (they share), the male having twice the share of the female. Thus doth God make clear to you (His law), lest ye err. And God hath knowledge of all things. ${ }^{17}$

Of the three verses, the followings are shares of each heir:

Rights of children to inherit:

1. Share of a son is equal to two shares of daughter (surah An Nisa verse 11).

2. Share of two or more daughters are two thirds (surah An Nisa verse 11).

3. Share of a daughter is a half (surah An Nisa verse 11).

Rights of parents to inherit:

1. Share of parents, father and mother, each is a sixth if the deceased leaves child (surah An Nisa verse 11).

2. If parents is the only heirs, the deceased leaves no child and sibling, share of mother is a third (surah An Nisa verse 11).

3. Share of mother is a sixth if the deceased leaves no child but sibling (surah An Nisa verse 11).

Rights of husband and wife to inherit:

1. Share of husband is a half if the deceased leaves no child (surah An Nisa verse 12).

2. Share of husband is a fourth if the deceased leaves child (surah An Nisa verse 12).

3. Share of wife is a fourth if the deceased leaves no child (surah An Nisa verse 12).

4. Share of wife is an eighth if the deceased leaves child (surah An Nisa verse 12).

Rights of brothers and sisters to inherit:

1. If the deceased leaves a brother or a sister, each one of the two get a sixth (surah An Nisa verse 12).

2. If the deceased leaves two or more brothers and or sisters, their share is a third (surah An Nisa ayat 12).

3. If the deceased leaves a sister, her share is a half (surah An Nisa verse 176).

${ }^{16}$ Ibid., 71.

${ }^{17}$ Ibid., 94. 
4. If the deceased leaves a brother, he takes the inheritance (surah An Nisa verse 176).

5. If the deceased leaves two sisters, their shares is two-thirds (between them)(surah An Nisa verse 12).

6. If the deceased leaves brothers and sisters, (they share), the male having twice the share of the female (surah An Nisa verse 176).

Of some provisions of the inheritance, Shafi'i and Hazairin have different interpretations in practice, especially regarding kalalah. Term of kalalah is mentioned on surah An Nisa verse 176. It affects to shares of sibling as mentioned on surah An Nisa verses 12 and 176.

According to Hazairin, kalalahisthe deceased leaves no son and daughter and their descendant both male and female. In this position, brother or sister is heir of the deceased. Share of brother or sister is determined on surah An Nisa verse 12 if father survives.If father is died before the deceased, share of brother or sister is determined on surah An Nisa verse 176. Hazairin does not distinguish full sibling, consanguine, and uterine who have same shares.

Shafi'i defines kalalahis the deceased leaves no son, son of son, and father. In this condition, the deceased is kalalah, sibling will be entitled to inherit. Surah An Nisa verse 12 is used to uternity. Surah An Nisa verse 176 is used to full sibling and consanguine.

Compilation of Islamic Law combines Shafi'i and Hazairin opinions. According to Neng Djubaedah, based on provisions of the Compilation, the Compilation defines kalalah is the deceased leaves no son and daughter, descendant of son and daughter, and father. In this matter, the Compilation determines shares of uternity different from shares of full sibling and consanguine. Article 181 of the Compilation determines that share of uternity same as surah An Nisa verse 12. Article 182 of the Compilation determines share of full sibling and consanguine same as surah An Nisa verse 176.

\section{Syafi'i's (patrilineal) system of inheritance law}

a. Classifications of heirs

Classifications of heirs in shafi'i system of inheritance law arezul fara'id, asabah, andzul arham.Zul fara'idis the heirs who have certain shares in certain circumstances. The heirs of zul fara'id are a daughter and more without son, mother, father with child, wife, husband, one or more uternity, a full-sister or more without a full-brother.Asabahis the heirs who have unspecified or open or remain shares. Shafi'i divides asabah into three forms, namely ashabah bin nafsih, ashabah bil ghairi, and ashabah mal ghairi. Zul arhamis the heirs exclude zul fara'id and asabah.They are descendant of daughter and entitled to inherit if no zul fara'id (with blood relationship) and asabah heirs. The heirs of zul arhamare son and/or daughter of daughter of the deceased, and descendant through female link.

\section{Hazairin's (bilateral) system of inheritance law}

a. Classification of heirs

Hazairin classified heirs into three groups, namelyzul fara'id, zul qarabat, dan mawali.Compare to classification of heirs of Shafi'i, there are differences between them. The difference is term of group of heirs who receive 
unspecified shares. Shafi'i called asabah, but Hazairin called zul qarabat. Zul qarabat is heirs who received unspecified or open shares. The heirs of zul qarabat is son, daughter if inherit with son, father without child, brother without father, sister if inherit with brother without father. Another difference is form of group. Shafi'i identified zul arham, but Hazairin identified mawali, not zul arham. The latest difference is due to understanding of shape of society. Shafi'i gives priority to paternity than maternity, so descandent of maternity is blocked by zul fara'id and asabah.Hazairin stated that shape of society of al Qur'an and the hadith is bilateral which means that paternity and maternity have same position, no superiority. Thus, Hazairin did not identified group of zul arham, but mawali. Mawali is substituted heirs, such as child of child (grandchild of the deceased), parents of parents (grandparents of the deceased), or child of sibling (nephew or niece of the deceased). Both Shafi'i and Hazairin identify zul fara'id, agreed that Allah swt determined through al Qur'an specified shares for zulfara'id.

\section{b. The primary group of heirs}

In addition to classify heirs, Hazairin classifies the primary group of heirs based on surah Al Anfal (8) verse 75, surahAl Ahzab (33) verse 6, hadith Ibnu Abbas, and atsar Zaid bin Tsabit. The function of the primary group of heirs is as determinant of one entitled to inherit than the others.The primary group of heirs are:

1. The first primary group, son and daughter and their descendents or mawali, parents (father and mother), and husband or wife.

2. The second primary group, brother and sister and their descendent or mawali, mother, father, and husband or wife.

3. The third primary group, mother, father, and husband or wife.

4. The fourth primary group, husband or wife, mawaliof mother, andmawaliof father.

The four primary groups are applied sequentially from beginning to an end, not applied simultaneously instead of one group by another.If the deceased leaves child or mawali of child, the heirs are the first primary group. The core of the group is survived child or mawali of child.If the deceased leaves no child and or mawali of child but sibling, the heirs are the second primary group. The core of the group is survived sibling and or mawali of sibling. If no child, mawali of child, sibling, nor mawali of sibling, the heirs is the third primary group. The fourth primary group is entitled to inherit if no child, mawali of child, sibling, mawali of sibling, father, and mother. Husband and wife are exist in all primary groups.

\section{Compilation of Islamic Law system of inheritance law}

Compilation of Islamic Law is a special regulation for Indonesian muslim. The regulation consists of marriage, inheritance, and waqf. Purpose of the compilation is to serve as guidelines for judges of Religious Judicature in resolving cases. Prior to the compilation, they used 13 books as a guide to settle cases. Principally, provisions of the compilation have no different from al Qur'an. Nonetheless, it determined specified provisions than al Qur'an. 


\section{a. Classifications of heirs}

Compilation of Islamic Law does not determine classifications of heirs particularly. Of the provisions of inheritance concluded there are three classifications of heirs, namely zul fara'id, asabah, andsubstituted heirs. The groups of zul fara'id and asabah are same as classifications of heirs of Shafi'i about zul fara'id and asabah. The group of substituted heirs is more like mawali of Hazairin's classification. The difference is the compilation only determines subtituted heirs of child, but not determines substituted heirs of parents (father and mother).

\section{Inheritance Law of Civil Code}

Law of inheritance is one of laws written in the Civil Code, on BookIIconcerning Property ${ }^{18}$ According to Surini Ahlan Sjarif and Nurul Elmiyah, reasons of placement inheritance law in Book II of the Civil Code are

a. Rights to inherit identified as rights of property provided on Article 528 of the Civil Code.

b. Rights to inherit is one of ways to obtain rights of property, as defined on Article 584 of the Civil Code. ${ }^{19}$

Völmar stated thatreasons of placement of inheritance law in Book II of the Civil Code are

a. Rights to inherit is independent rights that could be sold (Article 1537 of the Civil Code).

b. Rights to inherit is able to be given as rights to collect hasil atas benda peninggalan (Article 957 of the Civil Code).

c. Rights to inherit is able to be sued to obtain inheritance (Article 834 of the Civil Code). ${ }^{20}$

According to Pitlo, reasons to put inheritance law on Book II of the Civil Code are rights to inherit only belongs to heirs, not the deceased.Through rights to inherit, heirs shall obtain the objects, rights, and piutang of the deceased, and are able to sue anyone who violates their rights. These show that rights to inherit is independent. ${ }^{21}$

The Civil Code divides heirs into two kinds, namely heirs of ab intestato and heirs of testamentair. Heirs of ab intestato is heirs due to marriage and kinship relations. Heirs of testamentair is heirs pointed in testament or wills.

There are classifications of heirs of ab intestato. The meaning of classification of the Civil Code is different from classification of heirs in Islamic inheritance law.Classification of the Civil Code have same meaning as the primary group of Hazairin, which groups entitled to inherit in order.

Classifications of heirs set forth in the Civil Code are

1) Child or offspring and wife or husband.

2) Parents (father and mother) and sibling.

3) Grandfather and grandmother or other ancestors in a straight line upward.

\footnotetext{
${ }^{18}$ Civil Code consists of four books, namely Book One about Person, Book Two about Objects, Book Three about Contract, and Book Four about Evidence and Expiry.

${ }^{19}$ Surini Ahlan Sjarif and Nurul Elmiyah,(2010).Hukum Kewarisan Perdata Barat: Pewarisan Menurut Undang-Undang, Jakarta: Kencana and Badan Penerbit FHUI, p. 9.

${ }^{20}$ Abdulkadir Muhammad,(2010). Hukum Perdata Indonesia, Bandung, Citra Aditya, p. 195-196.

${ }^{21}$ Ibid., 196.
} 
4) Relatives of side line until the sixth degree.

The first group of heirs, child or offspring and wife or husband, determined on Article 852 of the Civil Code.Each child whether from different marriage, man and woman, have the same share.Wife or husband, if they have child, has same share with child.If the marriage is not the first marriage of the deceased, and having child, share of wife or husband is not more than the smallest share of children. Wife or husband should not get a share more than a fourth. If wife or husband and other heirs of testamentair inherit together, she or he is able to withdraw all or part of furniture.

The second group of heirs, parents (father and mother) and sibling, determined on Article 854-859 of the Civil Code. They can inherit if the first group not exist. Father and mother, each of them has a third if the deceased leaves a sibling. Father and mother, each of them has a fourth if the deceased leaves more than one sibling, the remain two fourth is for sibling.

This provisions would be different if one of parents is survived, father or mother.Father or mother gets a half if a sibling is survived, the remain distributed to him or her. Share of father or mother is a third if the deceased leaves two siblings, the remain (two third) distributed to them.If the deceased leaves more than two siblings, father or mother get a fourth share, the remain (three fourth) distributed to them.

When parents died before the deceased, entire estate belongs to siblings in equal share between them.If the deceased has consanguine or uternity, the estate divided into two parts. One part is for paternity (consanguine) and another is for maternity (uternity). Full sibling gets a share of both. If the heirs is only father or mother without sibling, father or mother inherit entire estate.

The third group of heirs, grandfather and grandmother or other ancestor in a straight line upward, determined on Article 853 of the Civil Code.Firstly, property divided into two parts (kloving). One part is for blood relatives in the paternal line straight up, and another is for blood relatives in the maternal line straight up.This distribution gives possibility that degree of heirs of one line is farther than another. In Article 861 paragraph (2) determined that if there is no heirs of one line, heirs of another line will inherit entire estate. In addition,the closest family closes further degree of family from the deceased.

The fourth class of heirs are relatives of the side line until the sixth degree. The heirs until the sixth degree are:

1. The first degree is the deceased.

2. The second degree is parents of the deceased.

3. The third degree is sibling of parents (uncle or aunty of the deceased).

4. The fourth degree is child of parents' sibling (cousin of the deceased).

5. The fifth degree is child of child of parents' sibling (child of cousin of the deceased).

6. The sixth degree is child of child of child of parents' sibling (grandchild of cousin of the deceased).

To distribute legacy, we do kloving, it is to divide into two parts for family of father line and family of mother line. Then the part distributed to the closest degree of heirs from the deceased. If there is no heir on one of family lines, another family line will inherit entire estate.

It is possible that the heirs of class four inherit along with heirs of class 
three because of kloving.If kloving has been made for father line and mother line, the estate distributed according to faction.For example, in paternity there is heirs of class three then kloving of paternity given to the heirs. If there is no heirs of class three in maternity, but heirs of class four, then kloving of maternity given to the heirs.

On heirs of testamentair, the deceased have to provide will in his or her life. Contents of the will is appointment of beneficiary (erfstelling) or grant (legat). Testament of erfstelling consists of distribution of all or part of estate to one or more when he or she died. Testament of grant is about distribution of one or some specific objects, all of particular object, or rights to collect result of entire or some estates to one or more. Amount of wills will not reduce the absolute share of heirs (legitieme portie).

\section{Personality Principle}

Of the three systems of inheritance law, the implementiation of the systems is based on personality principle. Personality principle is a principle based on individual or personal condition. Regarding inheritance, explanation of the condition is ditermined in legislation.

\section{A. The Civil Code}

In the period of Dutch Government, Indonesian people were differentiated by class. It was determined on Article 131 jo. Article 163 Indische Staatsregeling, that is:

a. Dutch people.

b. European people.

c. Japanese people, excluded first and second classes submit to the law which have same legal principles of family.

d. People born in Indonesia as legitimate or legally recognized and descendants of second and third classes.

Article 131 jo Article 163 Indische Staatsregeling determined that inheritance law of KUHPer was applied to second class and people equated to second class. Based on Staatsblad 1917 No. 129, inheritance law of the Civil Code applied to group of Chinese Foreign East. Based on 1924 No. 557, inheritance law ofthe Civil Code applied to Chinese Foreign East in Indonesia.

In Article 66 of Law No. 1 Year 1974 concerning Marriage, it is determined that provisions of the Civil Code, Ordonansi Perkawinan Indonesia Kristen (Huwelijks Ordonnantie Christen Indonesiers S. 1933 No. 74), Regulation of Mixed Married (Regeling op de gemengde Huwelijken $S$. 1898 No. 158), andothers regulations related to marriage are not valid if it is regulated in Law of Marriage. In this case, Subekti argued that the Civil Code and others are valid if not regulated in Law of Marriage.Since Law of Marriage not regulates inheritance, provisions of inheritance in the Civil Code are valid. It is confirmed in Surat Edaran Mahkamah Agung(Circular Letter of Supreme Court) to Chairman/Judges of Appel- 
late Court andChairman/Judges of Civil Court on August 20, 1975 No. M.A./Penb/0807/75 concerning implementation of Lawof Marriage and PP (Government Regulation) No. 9 Year 1975.

Inheritance law of the Civil Code is for people subject or subjecting themselves to the Civil Code. Effendi Perangin stated thatlegal entity who subject to inheritance law of the Civil Code is Indonesian citizens of Chinese and European.

\section{B. Law No. 3 Year 2006}

Inheritance law is conducted when someone is died, left property and survived heirs. Applying inheritance law is neededofficial registration to give a statement of heirs names, shares of heirs, amount and kinds of property. Before occupying of Netherlands to Indonesia, settlement of inheritance disputes was conducted by ulama. In period of Dutch Government, religious court was established to settle disputes related to Islamic law, included inheritance. However, Staatsblad 1937: 116 Article 2a paragraph (1)revoked authority of religious court in settling disputes of islamic inheritance.Based on research of Daniel S. Lev, he found that muslim kept submitting the dispute of inheritance to religious court. In this situation, judge did not make decision or verdict but fatwa. ${ }^{22}$

Law No. 7 Year 1989 gives authority of inheritance dispute settlement to religious court. In this Act, muslim had choice of law to solve their inheritance disputes. Thus, this regulation give a chance to muslim to not obey Islamic law. Obviously, it is against sharia, which muslim must obey the divine law stated in al Qur'an, including the inheritance law.

In 2006, Law No. 7 Year 1989 was amended by Law No. 3 Year 2006 concerning Amendment of Law No. 7 Year 1989 concerning Religious Judicial. In this Act, there is a very important amendment in settlement of inheritance disputes. Specified in the General Explanation that no more choice of law to settle inheritance disputes. If the deceased is muslim, Islamic law must be applicable to the inheritance, namely the property, the heirs, and the law. Therefore, the disputes have to be submitted to religious court.

Abdulkadir Muhammad stated in his book Hukum Perdata Indonesiathat "Bagi warga negara Indonesia yang tunduk pada sistem hukum agama dan hu kum adat, KUHPdt merupakan alternatif yang dapat dipakai sebagai dasar menyelesaikan masalah yang beragam dalam masyarakat ${ }^{\prime 23}$

(For Indonesian citizens who subject to systems of religious and adat law, the Civil Codeis an alternative to be used as basis for solving problems in society).

The Civil Code is complementary as long as none of provisions in religious law and adat law.

${ }^{22}$ Daniel S. Lev,(1986).Peradilan Agama Islam di Indonesia: Suatu Studi tentang Landasan Politik Lembaga-lembaga Hukum, Jakarta: Intermasa, p. 248-250. Provision of the staatsblad was influenced by Staatsblad 1929 : 134 as reception of Islamic law to adat law, an implementation of receptie theory of Snouck Hurgronje. See Sajuti Thalib,(1985).Receptio A Contrario: Hubungan Hukum Adat dengan Hukum Islam, Jakarta: Bina Aksara,p. 37-40 and Robert Pringle, Understanding Islam In Indonesia: Politics and Diversity, (Singapore: EDM, 2010), 46-52.

${ }^{23}$ Ibid., v. 


\section{Cases}

Settlement of inheritance disputes is submitted to Civil Court and Religious Court.Judge of Religious Court uses islamic law and related legislation to resolve the dispute. While the inheritance dispute submits to Civil Court, will be resolved by adat or western law. Previously described in section III B. Law No. 3 Year 2006 that Religious Court has authority to settle inheritance dispute if religion of the deceased is Islam.

\section{A. Sebayang vSinulingga}

1. Case:

In 2000, Teranah $\mathrm{Br}$ Sebayang (the deceased) died. She left three sisters(Minter Br Sebayang, Dame Br Sebayang, and Roneng Br Sebayang), anddaughters (Marta Br Sebayang and Norma Br Sebayang) and sons (Sabar Sebayang and Merdeka Sebayang) of her absence-brother(Ndeman Sebayang).Before Teranah Br Sebayang died, she married Akum Sinulingga (died 1998) who had a son (Mawardi Sinulingga) and two daughters (Diana Br Sinulingga and Murni Sinulingga) from previous marriage with Temben Br Perangin-angin (died 1995).

Teranah Br Sebayang left property, acquired during her marriage with Akum Sinulingga, consists of two tracts of land at Pematang Johor Village anda tract of land and house at Kabanjahe City. The entire property was occupied by Mawardi Sinulingga, Diana Br Sinulingga, and Murni Sinulingga. Sebayang assumed that the heirs of Teranah Br. Sebayang was Sebayangbecause Teranah Br Sebayang left no child. Sinulingga assumed that the heirs of Teranah Br. Sebayang was Sinulingga because Teranah Br Sebayang had been clan of Sinulingga. Therefor, the properties belonged to Sinulingga.

2. Verdicts:

a. Civil Court of Lubuk Pakam

Judges of the court decided (Putusan No.13/Pdt.G/2002/PN.LP) that:

i. The heirs of Teranah Br Sebayang areher three sisters (Minter $\mathrm{Br}$ Sebayang, Dame Br Sebayang, and Roneng Br Sebayang), and daughters (Marta Br Sebayang and Norma Br Sebayang) and sons (Sabar Sebayang and Merdeka Sebayang) of her absence-brother (Ndeman Sebayang).

ii. The entire property is boedel (legacy).

iii. Half of boedel is distributed to the heirs.

b. Appellate Court of Medan

Judges of Appellate Court of Medan decided (PutusanNo. 78/Pdt/2004/ PT.Mdn) to revoke Verdict of Civil Court of Lubuk Pakam.

c. Supreme Court

Judges of Supreme Court decided (Putusan No. $649 \mathrm{~K} / \mathrm{Pdt} / 2009$ ) that verdict of Appellate Court of Medan is no mistake in applying the law because it is in accordance with law and/or legislation. 
3. Adat inheritance law $v$ western inheritance law

Case of Sebayang v Sinulingga is contraditary between adat inheritance law and western inheritance law. Sebayang dan Sinulingga are from indigenous Karo (North Sumatera) which has patrilineal descent system with individual inheritance system.In Karo peoples, woman must marry with different clan from her.Once married, she will be part of her husband's clan.Based on the descent system, it influences the legacy property of the woman (the deceased).It belongs to husband's clan. Thus, the family of woman's clan not entitled to inherit.

In this case, Sinulingga argued that adat inheritance law remains in force for them, so they have rights to occupy and manage the property. Sebayang had different argument. Based on provisions in the Civil Code, Sebayang argued that they are entitled to the property and included the second group.They stated that Karo tradition with patrilineal system is only in the period before World War II (1938)as referred to Jurisprudence (Verdict) of Indonesian Supreme Court No. 1310 K/Sip/1973 30 dated September 1975 andJurisprudence (Verdict) No. 283 K/Sip/1975 dated 8 September 1976.

Judges of Civil Court applied western inheritance law to case of Sebayang v Sinulingga. Distribution of boedel, for Sebayang and Sinulingga, is based on Civil Code. However, the judges of Appellate Court applied adat (Karo) inheritance law to this case, so they revoked the verdict of the Civil Court.Verdict of Appellate Court reinforced by the Supreme Court rejected appeal of Sebayang to apply the Civil Code to their case. This case shows that people and judges still implement adat inheritance law.

\section{B. Endin v Ali and Endin}

1. Case:

Endin bin Tahami (died 1964) was married three times:

a. The first wife was Zubaedah, then divorced. They had a daughter, named Aminah binti Endin (died 1986). Aminah had a son (Fataholah bin Hasim) and four daughters (Enun binti Beni,Siti Zubaedah binti Hasim, Mahnaf binti Amir, dan Hafsah alias Sun binti Amir).

b. The second wife was Jamilah binti Ambe (died 1955). They had a daughter, named Hafsah binti Endin (died 1957). Hafsah had a daughter, named Sompawati binti Abdul Kapi.

c. The third wife was Obo binti Muhammad (died 1960). They had a son, named Abu Bakar bin Endin.

After Endin bin Tahami died, Abu Bakar bin Endin was cared to adult by Endin's nephew, namely H.M. Ali bin Anwar.

During his marriage with Jamilah binti Ambe, they had common property consists of a tract of rice field and plants at Peliuk Berang Sebeda Watasan anda tract of rice field at Peliuk Tamere Watasan, both located in Rhee Loka Village, Sumbawa. The common propertywas not distributed to the heirs yet, but is occupied by Abu Bakar bin Endin andH.M. Ali bin Anwar. After H.M. Ali bin Anwar died in 2007, the properties were occupied by his children, namely M. Jayadi bin H.M. Ali, Muslim bin H.M. Ali, Munajad bin H.M. Ali, Mini binti H.M. Ali, and Mustiadi alias Rendi bin H.M.Ali. 
2. Verdicts:

a. Religious Court of Sumbawa Besar Judges of Religious Court of Sumbawa Besar decided (Putusan No. 166) Pdt.G/2009/PA.Sub) that:

i. Determined that two tracts of rice fields and the plants are common propertyof Endin bin Tahami and Jamilah binti Ambe.

ii. Determined that the distribution of common property is half to Endin bin Tahami and half to Jamilah binti Ambe.

iii. Determined that share of Jamilah binti Ambe (half of common property) is the legacy property which is yet to inherit to her heirs.

iv. Determined that the heirs of Jamilah binti Ambeandtheir shares are:

a. Endin bin Tahami (husband), the share isquarter of the legacy property.

b. Hafsah binti Endin (daughter) was the absence heir who left a daughter, Sompawati.Her share is third-quarter of the legacy property, which given to Sompawati.

v. Determined that $1 / 2+2 / 16=10 / 16$ (ten of sixteen) of the legacy property is the estate of Endin binTahami that has not been inherit to his heirs.

vi. The heirs of Endin bin Tahami are:

a. Aminah binti Endin (daughter) had died and had left five children. The shares of them are:

i. Fataholah (son): 2/6 of the legacy;

ii. Siti Zubaedah (daughter): 1/6 of the legacy;

iii. Enun (daughter): 1/6 of the legacy;

iv. Mahnaf (daughter):1/6 of the legacy;

v. Hafsah alias Sun (daughter):1/6 of the legacy.

b. Abu Bakar bin Endin (son) has share of 2/5 of the legacy.

c. Sompawati,as substitute heir of Hafsah binti Endin,has share 1/5 of the legacy. Therefor, the whole share of Sompawati is $2 / 16+6 / 16=$ $8 / 16$ of the legacy.

vii.H.M. Ali bin Anwar has share 1/5 of the legacy obtained by wasiat wajibah.His heirs are:

a. Share of M. Jayadi is 2/9 of the legacy of H. M. Ali;

b. Share of Muslim is 2/9 of the legacy ofH. M. Ali;

c. Share of Munajad is 2/9 of the legacy ofH. M. Ali;

d. Share of Mini is 1/9 of the legacy ofH.M. Ali;

e. Share of Mustiadi alias Rendi is 2/9 of the legacy ofH. M. Ali.

b. Religious Appellate Court of Mataram

Judges of Religious Appellate Court decided (Putusan No. 92/Pdt.G/2009/ PTA.Mtr.) to upheld and improved location and serial number of Religious Court Verdict of Mataram. 
c. Supreme Court

Judges of Supreme Court decided (Putusan No. $316 \mathrm{~K} / A G / 2010$ ) that Religious Appellate Court of Mataram not misapplied the law. In addition, the reasons of evidence assessment as award of a fact can not be considered on this level,andverdict ofReligious Appellate Court is not against the law and/or legislation.

\section{System of Islamic Inheritance Law}

In the case of Endin v Ali and Endin, judges used provision of KHI eventhoughthey do not write legal basis of KHI in verdict. They determined that child of daughter of the deceased to inherit the legacy. It is different from system of Syafi'i inheritance law that children of daughter of the decease will not inherit because of survival son of the deceased. Sompawati, grandchild of Endin bin Tahami (the deceased), is substituted heir of her mother, Hafsah bin Endin (daughter of the deceased), eventhough Abu Bakar bin Endin (son of the deceased) is survived. All of judges of Religious Court, Religious Appellate Court, and Supreme Court have the same opinion on this.

\section{Manurung vNainggolan}

1. Case:

Zainal Abidin Nainggolan married Hotmaida Br Sinaga. They had two sons (died when were kids) and two daughters, Zubaidah Br Nainggolan and Saria Br Nainggolan. Saria Br Nainggolan married Jamuda Manurung and have nine sons, namely Halomoan Manurung, Tulus Manurung (the late), Kaisar Manurung (the late), Pangaloan Manurung, Binsar Manurung, Udin Ronggur Manurung, Oloan Manurung, Rohinim Manurung (the late), andSabarniati Manurung.Zainal Abidin Nainggolan and his second wife, Tioman Br Sirait,had a son, Abdul Jabar Nainggolan. Then Abdul Jabar Nainggolan marriedNursiah Br Siahaan.

In the marriage of Zainal Abidin Nainggolan and Hotmaida Br Sinaga, Hotmaida Br Sinaga brought her property into her marriage. It was a tract of land as a gift from her brother, Benyamin Sinaga (Tuan Panahatan) located at Nagari Bandar Dolok, Simalungun. They controlled and took care of the land. Since Hotmaida Br Sinaga died in 1935, the land was taken care byher husband, Zainal Abidin Nainggolan, and daughters, Zubaidah Br Nainggolan and Saria Br Nainggolan. Then, Zubaidah Br Nainggolan and Saria Br Nainggolan took over the land since 1945 when Zainal Abidin Nainggolan died. In 1956, Tioman Br Sirait took over the land because Zubaidah Br Nainggolan was died and Saria Br Nainggolan married Jamuda Manurung. In 2003 Tioman Br Sirait died, so the land was taken over by Abdul Jabar Nainggolan andhis wife, Nursiah Br Siahaan.

\section{Verdicts:}

a. Civil Court of Simalungun

Judges of Civil Court of Simalungun (Putusan No. 25/Pdt.G/2008/ PN.Sim) decided that: 
1. The land is legacy (estate) of Hotmaida Br Sinaga.

2. Heirs of Hotmaida Br Sinaga are Halomoan Manurung, Tulus Manurung (the late), Kaisar Manurung (the late), Pangaloan Manurung, Binsar Manurung, Udin Ronggur Manurung, Oloan Manurung, Rohinim Manurung (the late), andSabarniati Manurung who entitle to the land.

3. Heirs have rights to keep and take care of the land before they distribute to the heirs.

b. Appellate Court of Medan

Judges of Appellate Court of Medan (Putusan No.138/Pdt/2008/PT.Mdn) decided that verdict of Civil Court of Simalungun is not acceptable and revoked.

c. Supreme Court

Judges of Supreme Court (Putusan No. $3023 \mathrm{~K} / \mathrm{Pdt} / 2009$ ) tried the case and decided that Civil Court of Simalungun andAppellate Court of Medan had missapllied the law because they had no authority to try the case.Eventhough the case was related to dispute of ownership, but the plaintiffs and the defendants were muslim. The case was supposed to be submitted to the Religious Court, as provided in Article 50 paragraph (2) Law No. 3 Year 2006.

\section{Inheritance law of adat, western, and Islam}

Case of Manurung v Nainggolan is a clash between adat, western, and Islamic inheritance laws. According to adat law, estate of Hotmaida Br Sinaga belongs to the Nainggolan because Hotmaida Br Sinaga is part of the Nainggolan since married Zainal Abidin Nainggolan. In addition, they have no son who continue the clan.Therefore, the land was taken over by Tioman Br Sirait (Zainal's second wife). Saria Br Nainggolan could not take care of the land because not part of the Nainggolan since her marriage with the Manurung.

Judges of Civil Court of Simalungun did not consider adat law to the case, but the Civil Code. They considered source of the asset belonged to Hotmaida Br Sinaga, not the Nainggolan. Therefore, it must be distributed to heirs of Hotmaida Br Sinaga, the Manurung, though they are different clan from Hotmaida Br Sinaga.The judges of Supreme Court is more positivist to resolve the case. Based on Law No. 3 Year 2006, there is no choice of inheritance law for muslim. Muslim have to submit case to Religious Court. Therefore, they decided that the verdict of Appelate Court is revoked.

\section{Conclusion}

The three systems of inheritance law in Indonesia, adat, Islam, and western, are remain in force and implemented to date. The use of the systems can be seen in inheritance disputes. In the society, it has been changed of shifted in the inheritance norms from adat law to western law, or adat law 
to islamic law.This can be seen from the reasons of the parties to disputes in courts, like Sebayang v Sinulingga and Manurung v Nainggolan who applying adat law to acquisition of property to the clan of male lineage and willing to apply western law to have the property to the clan of female lineage.It happened as well as case of Endin v Ali and Endi, shifting of inheritance norms from Syafi'i inheritance to KHI inheritance system. Grandchildren of daughter become heir, in which it does not apply to the system of Syafi'i inheritance.

In implementing inheritance law, parameter of legal justice can not be determined correctly unless determined by law or legislation.To implement islamic inheritance law, it is clearly stated in the Law No. 3 Year 2006 that if the deceased is muslim, the prevailing inheritance law is islamic law.In practice, there is different interpretation of the provision regarding disputes of ownership. As a result, Civil Court and Appellate Court do not refuse to try the case. However, the highest judges (of Supreme Court) argued that they have no authority. In the respect of authority, the judges should understand purpose of the provisions in order to have same interpretation.

In contrat to adat and western law, they have no specified regulation related to principle of personality. As mentioned before, western law is applied for particular groups and adat law is applied for indigenous. For Chinese non-muslim, they will use the Civil Code to implement inheritance.But, for Indonesian non-muslim, they are possible to choose adat law or the Civil Code. Problem is emerged when among the heirs choose different law. The difference choosing law is happened because of two possibilities. They try to get profit from the law or they have changing values of inheritance law since living in different environment.

\section{Bibliography}

\section{Books}

'Ali, 'Abdullah Yusuf,(1994). The Holy Quran: Text and Translation. Kuala Lumpur: Islamic Book Trust.

Djubaedah, Neng and Yati N. Soelistijono,(2008). Hukum Kewarisan Islam di Indonesia. Jakarta: BP FHUI.

Hadikusuma, Hilman,(1993). Hukum Waris Adat. Bandung: Citra Aditya Bakti. Hazairin.(1982). Hukum Kewarisan Bilateral menurut Qur'an dan Hadith. Jakarta: Tintamas Indonesia.

Lev, Daniel S,(1986). Peradilan Agama Islam di Indonesia: Suatu Studi tentang Landasan Politik Lembaga-lembaga Hukum. Jakarta: Intermasa.

Marzuki, Peter Mahmud,(2011). An Introduction to Indonesian Law. Malang: Setara Press.

Marican, Pawancheek,(2008). Islamic Inheritance Laws in Malaysia. Selangor Darul Ehsan: Lexis Nexis.

Muhammad, Abdulkadir,(2010). Hukum Perdata Indonesia. Bandung: Citra Aditya Bandung.

Perangin, Effendi,(2010). Hukum Waris. Jakarta: RajaGrafindo Persada.

Pringle, Robert,(2010). Understanding Islam In Indonesia: Politics and Diversity. Singapore: EDM. 
Satrio, J,(1992). Hukum Waris. Bandung: Penerbit Alumni.

Sjarif, Surini Ahlan and Nurul Elmiyah,(2010). Hukum Kewarisan Perdata Barat: Pewarisan menurut Undang-Undang. Jakarta: Kencana and BP FHUI.

Subekti and R. Tjitrosudibio, trl,(2009). Kitab Undang-Undang Hukum Perdata [Burgerlijk Wetboek]. Jakarta: Pradnya Paramita.

Thalib, Sajuti,(2008). Hukum Kewarisan Islam di Indonesia. Jakarta: Sinar Grafika.

Thalib, Sajuti,(1985). Receptio A Contrario: Hubungan Hukum Adat dengan Hukum Islam. Jakarta: Bina Aksara.

\section{Legal Documents}

Kompilasi Hukum Islam.

Undang-Undang No. 3 Tahun 2006 tentang Perubahan Atas Undang-Undang No. 7 Tahun 1989 tentang Peradilan Agama.

\section{Cases}

Endin v Ali and Endin. Putusan No. 316 K/AG/2010.

Manurung v Nainggolan. Putusan No. $3023 \mathrm{~K} / \mathrm{Pdt} / 2009$.

Sebayang v Sinulingga. Putusan No. 649 K/Pdt/2009. 